\title{
Physical characteristics and chemical-nutritional composition of the castanheira-do-gurguéia fruit (Dipteryx lacunifera Ducke) ${ }^{1}$
}

\author{
Características físicas e composição químico-nutricional do fruto de castanheira-do- \\ gurguéia (Dipteryx lacunifera Ducke)
}

\author{
Francisca Samara de Carvalho Ribeiro ${ }^{2 *}$, Valdomiro Aurélio Barbosa de $\operatorname{Souza}^{3}$ e Ângela Celis de Almeida \\ Lopes $^{4}$
}

\begin{abstract}
The castanheira-do-gurguéia is a native fruit tree with great regional importance, whose almond present pleasant flavor and exploration still limited. The objective of this research was to evaluate the physical and chemical-nutritional characteristics of 23 castanheira-do-gurguéia genotypes from natural occurrence areas of Piauí State southwestern savannah. A sample of 30 to 50 fruits per genotype was collected. The physical characteristics analyzed were: fruit mass, pericarp mass, fruit length, larger fruit thickness, fruit length/larger fruit thickness ratio, smaller fruit thickness, fruit length/smaller fruit thickness ratio, larger pericarp thickness, smaller pericarp thickness, longitudinal diameter of the pericarp cavity, vertical diameter of the pericarp cavity, almond mass, almond length, larger almond thickness, smaller almond thickness and almond length/larger almond thickness ratio. The following chemical-nutritional characteristics of almonds were analyzed: fat, crude protein, crude fiber, ash total carbohydrates, crude energy and minerals ( $\mathrm{P}, \mathrm{K}, \mathrm{Ca}, \mathrm{Mg}, \mathrm{Mn}, \mathrm{Fe}, \mathrm{Cu}$ and $\mathrm{Zn}$ ). The data were submitted to analysis of variance and genotypes means were compared by Scott-Knott's test at 5\%. There were differences among genotypes for all physical and chemical-nutritional characteristics evaluated, except $\mathrm{Ca}$ in the almonds. It was verified the presence of great phenotypic variability in the analyzed germplasm. The genotype G-3 is the most promising in terms of almond mass, almond length and larger almond thickness, and the genotypes G-7, G-10, G-13 and G-23 are the most promising in the chemical-nutritional composition.
\end{abstract}

Key words - Nut. Genetic vegetal. Savannah of Piauí.

\begin{abstract}
Resumo - A castanheira-do-gurguéia é uma fruteira nativa com grande importância regional, cuja amêndoa apresenta sabor agradável e exploração ainda limitada. O objetivo desta pesquisa foi avaliar as características físicas e químico-nutricionais dos frutos de 23 genótipos, provenientes de áreas de ocorrência natural da espécie nos cerrados do Sudoeste piauiense. Foram coletados de 30 a 50 frutos por genótipo. As características físicas analisadas foram: massa do fruto, massa do pericarpo, comprimento do fruto, espessura maior do fruto, relação comprimento do fruto/espessura maior do fruto, espessura menor do fruto, relação comprimento do fruto/espessura menor do fruto, espessura maior do pericarpo, espessura menor do pericarpo, diâmetro longitudinal da cavidade do pericarpo, diâmetro vertical da cavidade do pericarpo, massa da amêndoa, comprimento da amêndoa, espessura maior da amêndoa, espessura menor da amêndoa e relação comprimento da amêndoa/espessura maior da amêndoa. As seguintes características químico-nutricionais da amêndoa foram analisadas: gordura, proteína bruta, fibra bruta, cinzas, carboidratos totais, energia bruta e minerais $(\mathrm{P}, \mathrm{K}, \mathrm{Ca}, \mathrm{Mg}, \mathrm{Mn}, \mathrm{Fe}, \mathrm{Cu}$ e $\mathrm{Zn}$ ). Os dados foram submetidos à análise de variância e as médias dos genótipos foram comparadas pelo teste de agrupamento Scott-Knott a 5\%. Houve diferenças entre os genótipos para todas as características físicas e químico-nutricionais avaliadas, com exceção do teor de Ca da amêndoa. Foi verificada a presença de variabilidade fenotípica no germoplasma analisado. O genótipo G-3 é o mais promissor em termos de massa, comprimento e espessura maior da amêndoa e os genótipos G-7, G-10, G-13 e G-23 os mais promissores em conteúdo químico-nutricional.
\end{abstract}

Palavras-chave - Noz. Genética vegetal. Cerrado piauiense.

\footnotetext{
*Autor para correspondência

'Recebido para publicação 02/10/2010; aprovado em 03/10/2011

Parte da Dissertação de Mestrado da primeira autora

${ }^{2}$ Mestrado em Desenvolvimento e Meio Ambiente/MDMA/PRODEMA/TROPEN/Universidade Federal do Piauí, Campus Universitário Petrônio Portela, Teresina-PI, Brasil, 64.049-550, fsamcarvalho@yahoo.com.br

${ }^{3}$ Embrapa Meio-Norte, Av. Duque de Caxias 5650, Teresina-PI, Brasil, 64.006-220, (in memoriam)

${ }^{4}$ Departamento de Biologia/Universidade Federal do Piauí, Av. Universitária 1310, Teresina-PI, Brasil, 64.049-550, acalopes@ufpi.br
} 


\section{Introduction}

Brazil is one of the greatest repositories of the world's biodiversity, concentrating around 55000 species of superior plants, or $22 \%$ of the world's total, many of which are endemic (SILVA; BATES, 2002). Regarding native fruit species, the Central Brazil and the Northeast savannahs represent the country's second greatest genetic repository (RATTER; RIBEIRO, 1996).

Brazil's Northeast region presents a great diversity of native fruits, many of which have a good prospects for economic exploitation, such as hog plum (Spondias mombin L.), "pequi" (Caryocar coriaceum Wittm.), "bacuri", (Platonia insignis Mart.) and "baru" (Dipteryx alata Vog.), among others. There is also that species group which, despite its use potential, is known only locally, in some areas of the Northeast. This is the case of the "castanheira-do-gurguéia" (Dipteryx lacunifera Ducke), a species of natural occurrence in the savannah of the Southwest of Piaui State, where it is explored in an extractivist form by local's peoples, helping to supplement the family income.

The "castanheira-do-gurguéia" belongs to the Leguminoseae-Papilionoideae family and to the genus Dipteryx, which includes 14 species, all especially used as medicinal plants. In Brazil, these species can be found in the Amazon, Northeast, and Center-Western regions. Some are found in Venezuela and others in Central America, more specifically in Costa Rica and Panama (DUCKE, 1948). In turn, the species Dipteryx lacunifera Ducke is found in Brazil's Mid-North region, comprised by the states of Maranhão and Piauí, with a large occurrence in Piauí's Southwestern savannah. Vernacularly known as "garampara" and donkey's nut, the almond of "castanha-do-gurguéia" is a good source of energy, carbohydrate, crude protein and crude fiber; and this fact indicates, according to Carvalho et al. (2008), that this almond has potential use by the almond market.

However, the availability of information on this species is still scarce in the specialized literature (CARVALHO, 2005; CARVALHO, 2008; CARVALHO et al., 2008; VIEIRA JÚNIOR et al., 2007), and it is not enough to provide its sustainable management and use. Currently, it is exploited by the extractivism, with no reports on organized plantings. Thus, it is essential do researches that contribute to the increase of scientific knowledge about that species, and also to allow direct strategies favoring its conservation, advances in the domestication process, and its sustainable use.

This research aimed to evaluate the physical characteristics of the fruit (pericarp and almond), and the nutritional composition of the pericarp and almond of 23 genotypes of castanheira-do-gurguéia.

\section{Material and methods}

\section{Study area}

The research was carried out in three districts of Piauí's Southwestern Mesoregion: Bom Jesus, Alvorada do Gurguéia and Palmeira do Piauí, with natural occurrence of castanheira-do-gurguéia. These districts are located in the Microregion of Alto Médio Gurguéia, and their vegetation is mostly formed by the savannah (woodland savannah and dense savannah).

The previous selection of the genotypes of castanheirado-gurguéia was held in June 2008, when the plants had already well-developed fruits, while the fruits were collected in September 2008, the harvest peak month. Based on fruit production, 23 genotypes were selected and georeferenced (TAB. 1). A sample of 30 to 50 fruits per genotype was collected, depending on the availability of ripe fruit at the collection period. Once collected, fruits were packed in plastic bags, labeled and taken to the Plant Physiology Laboratory of EMBRAPA Mid-North, in Teresina, Piauí State, Brazil, where they were exposed to room temperature to dry out before starting physical measurements. The almond extraction was done manually, using a mechanical lathe, and for the physical measurements of the almond it was used a sample size of 10 almonds per genotype.

\section{Physical characterization of fruits}

Fruit physical measurements were done between October to December 2008 and the following characteristics were measured: fruit mass $(\mathrm{FM})$, pericarp mass (PM), fruit length (FL), larger fruit thickness (LFT), smaller fruit thickness (SFT), FL/LFT ratio, FL/SFT ratio, larger pericarp thickness (LPT), smaller pericarp thickness (SPT), longitudinal diameter of the pericarp cavity (LDPC), vertical diameter of the pericarp cavity (VDPC), almond mass (AM), almond length (AL), larger almond thickness (LAT), smaller almond thickness (SAT) and AL/LAT ratio. A precision digital scale was used to do mass measurements. The measurements of length, thickness and diameter were done with a digital caliper.

After the physical measurements, the samples were dried at $60{ }^{\circ} \mathrm{C}$, for 24 hours, in a forced-air circulation oven, and then the almonds were grounded in a multiprocessor, packed in plastic bags, labeled and stocked up at room temperature until the beginning of the almond chemical-nutritional analyses.

\section{Chemical-nutritional characterization of almonds}

The chemical-nutritional analyses were accomplished at the Bromatology Laboratory of EMBRAPA Mid-North and at the Animal Nutrition Laboratory of the Federal University of Piauí, both in Teresina, Piauí State, from April to August 2009. 
Table 1 - Geographical location of the castanheira-do-gurguéia genotypes collected in Piauís southwestern savannah

\begin{tabular}{|c|c|c|c|c|c|}
\hline Genotypes & Collection site & District & Altitude (m) & Latitude & Longitude \\
\hline G-1 & C. E. Embrapa Meio-Norte & Alvorada-do-Gurguéia-PI & 248 & $08^{\circ} 26^{\prime} 29^{\prime \prime}$ & $43^{\circ} 52^{\prime} 19^{\prime \prime}$ \\
\hline G-2 & C. E. Embrapa Meio-Norte & Alvorada-do-Gurguéia-PI & 251 & $08^{\circ} 26^{\prime} 29^{\prime \prime}$ & $43^{\circ} 52^{\prime} 19^{\prime \prime}$ \\
\hline G-3 & Pov. Pitombeira & Bom Jesus-PI & 328 & $09^{\circ} 16^{\prime} 14^{\prime \prime}$ & $44^{\circ} 16^{\prime} 28^{\prime \prime}$ \\
\hline G-4 & Pov. Pitombeira & Bom Jesus-PI & 339 & $09^{\circ} 16^{\prime} 17^{\prime \prime}$ & $44^{\circ} 16^{\prime} 44^{\prime \prime}$ \\
\hline G-5 & Pov. Pitombeira & Bom Jesus-PI & 323 & $09^{\circ} 16^{\prime} 18^{\prime \prime}$ & $44^{\circ} 16^{\prime} 44^{\prime \prime}$ \\
\hline G-6 & Pov. Pitombeira & Bom Jesus-PI & 369 & $09^{\circ} 15^{\prime} 58^{\prime \prime}$ & $44^{\circ} 15^{\prime}, 57^{\prime \prime}$ \\
\hline G-7 & Pov. Pati & Bom Jesus-PI & 341 & $09^{\circ} 11^{\prime} 07^{\prime \prime}$ & $44^{\circ} 14^{\prime} 34^{\prime \prime}$ \\
\hline G-8 & Pov. Pati & Bom Jesus-PI & 329 & $09^{\circ} 12^{\prime} 03^{\prime \prime}$ & $44^{\circ} 13^{\prime} 56^{\prime \prime}$ \\
\hline G-9 & Pov. Pati & Bom Jesus-PI & 333 & $09^{\circ} 12^{\prime} 02^{\prime \prime}$ & $44^{\circ} 13^{\prime} 57^{\prime \prime}$ \\
\hline G-10 & Pov. Pati & Bom Jesus-PI & 335 & $09^{\circ} 12^{\prime} 25^{\prime \prime}$ & $44^{\circ} 13^{\prime} 00^{\prime \prime}$ \\
\hline G-11 & Pov. Pati & Bom Jesus-PI & 342 & $09^{\circ} 12^{\prime} 28^{\prime \prime}$ & $44^{\circ} 12^{\prime} 60^{\prime \prime}$ \\
\hline G-12 & Pov. Corrente & Bom Jesus-PI & 340 & $09^{\circ} 11^{\prime} 26^{\prime \prime}$ & $44^{\circ} 32^{\prime} 04^{\prime \prime}$ \\
\hline G-13 & Pov. São Gonçalo & Bom Jesus-PI & 308 & $09^{\circ} 10^{\prime} 29^{\prime \prime}$ & $44^{\circ} 33^{\prime} 19^{\prime \prime}$ \\
\hline G-14 & Pov. Estreito & Bom Jesus-PI & 323 & $09^{\circ} 09^{\prime} 45^{\prime \prime}$ & $44^{\circ} 34^{\prime} 46^{\prime \prime}$ \\
\hline G-15 & Pov. Vereda Seca & Bom Jesus-PI & 328 & $09^{\circ} 09^{\prime} 21^{\prime \prime}$ & $44^{\circ} 35^{\prime} 31^{\prime \prime}$ \\
\hline G-16 & Pov. Escalvado & Bom Jesus-PI & 341 & $09^{\circ} 09^{\prime} 07^{\prime \prime}$ & $44^{\circ} 37^{\prime} 33^{\prime \prime}$ \\
\hline G-17 & Pov. Pati & Bom Jesus-PI & 324 & $09^{\circ} 11^{\prime} 23^{\prime \prime}$ & $44^{\circ} 14^{\prime} 14^{\prime \prime}$ \\
\hline G-18 & Pov. SantaTeresa & Bom Jesus-PI & 340 & $09^{\circ} 12^{\prime} 32^{\prime \prime}$ & $44^{\circ} 13^{\prime} 07^{\prime \prime}$ \\
\hline G-19 & Pov. Porteiras & Bom Jesus-PI & 350 & $09^{\circ} 11^{\prime} 28^{\prime \prime}$ & $44^{\circ} 13^{\prime} 24^{\prime \prime}$ \\
\hline G-20 & Pov. Porteiras & Bom Jesus-PI & 334 & $09^{\circ} 11^{\prime} 31^{\prime \prime}$ & $44^{\circ} 13^{\prime} 39^{\prime \prime}$ \\
\hline G-21 & Pov. Porteiras & Bom Jesus-PI & 332 & $09^{\circ} 11^{\prime} 27^{\prime \prime}$ & $44^{\circ} 13^{\prime} 43^{\prime \prime}$ \\
\hline G-22 & Pov. Pati & Bom Jesus-PI & 332 & $09^{\circ} 11^{\prime} 33^{\prime \prime}$ & $44^{\circ} 13^{\prime} 55^{\prime \prime}$ \\
\hline G-23 & Pov. Boa Sorte & Palmeira do Piauí-PI & 293 & $08^{\circ} 42^{\prime} 40^{\prime \prime}$ & $44^{\circ} 15^{\prime} 12^{\prime \prime}$ \\
\hline
\end{tabular}

C.E: Experimental Field; Pov.: Rural community

The chemical-nutritional characteristics of the almond analyzed were: fat, crude fiber, crude protein, ash, crude energy, total carbohydrate, and minerals $(\mathrm{Ca}, \mathrm{P}, \mathrm{K}, \mathrm{Mg}$, $\mathrm{Cu}, \mathrm{Mn}, \mathrm{Zn}$ and $\mathrm{Fe}$ ). The mineral concentrations it were determined by atomic absorption spectrophotometry.

The total carbohydrate concentration it was obtained through the formula $\mathrm{TC}=100-(\%$ crude protein + crude fiber + crude fat) and the crude energy was obtained by the formula: $\mathrm{CE}=$ crude protein $(\mathrm{g}) \mathrm{x} 4$ $\mathrm{kcal}+$ total carbohydrate $(\mathrm{g}) \times 9 \mathrm{kcal}+$ fat $(\mathrm{g}) \times 4 \mathrm{kcal}$. All the concentrations it were determined by the methods described on the analytical guidelines of (IAL, 2005).

\section{Data analysis}

For physical characteristics, it was considered a completely randomized statistical design with 23 treatments (genotypes), in which fruits and kernels per genotype were used as replications. For chemical-nutritional characteristics, it was also considered a completely randomized statistical design with 23 treatments (genotypes), but in this case with three replications per genotype of almonds.

Initially, it was performed residual analysis of the data with the aim of verifying the existence of differences and heterocedasticity of variances, adjustment of errors to the normal distribution, assumption of independence and additivity of the errors in the mathematical model.

Afterwards, the physical measurements and chemical-nutritional data were submitted to the variance analysis, with their means compared by Scott-Knott's test, at $5 \%$ of significance.

\section{Results and discussion}

The mean squares obtained from the analysis of variance for the physical characteristics of fruit and almonds, and for the chemical-nutritional characteristics 
of the almond are presented in Table 2 . The F test indicated significant differences among genotypes, evidencing the existence of genetic variability in the populations studied, as well as the perspective of genetic gain by selection for one or more of these characteristics. The coefficients of variation were mostly lower, evidencing precision in the measurements. With the exception of $\mathrm{Ca}$, the $\mathrm{F}$ test also indicated significant differences of the mean squares for the chemical-nutritional characteristics of almonds, evidencing the presence of genetic variability those characteristics among individuals and, therefore, the possibility to identify desirable individuals for using in future breeding programs in this species.

There were significant differences among genotypes for all physical characteristics of fruits (TAB. 3) and almonds (TAB. 4). The fruit mass (FM) and the pericarp mass (PM) showed the highest amplitude of variation. FM ranged from $6.36 \mathrm{~g}$ to $22.49 \mathrm{~g}$ and PM ranged from $5.76 \mathrm{~g}$ to $21.56 \mathrm{~g}$, and for both traits the

Table 2 - Summary of the analysis of variance for physical characteristics of fruits and almonds, and for chemical-nutritional characteristics of almonds in 23 genotypes of castanheira-do-gurguéia

\begin{tabular}{|c|c|c|c|c|}
\hline Characteristics & MQ (genotypes) & MQ (residue) & Mean & C.V. $(\%)$ \\
\hline \multicolumn{5}{|c|}{ Physical characteristics of fruits and almonds } \\
\hline FM & $307.09 * *$ & 10.76 & 15.76 & 25.88 \\
\hline FL & $159.46^{* *}$ & 8.73 & 38.11 & 8.26 \\
\hline LFT & $130.23 * *$ & 5.39 & 33.78 & 8.09 \\
\hline Ratio FL/LFT & $0.04 * *$ & 0.01 & 1.13 & 3.97 \\
\hline SFT & $77.14^{* *}$ & 2.54 & 22.38 & 8.61 \\
\hline Ratio FL/SFT & $0.24 * *$ & 0.02 & 1.72 & 7.48 \\
\hline PM & $285.62 * *$ & 10.13 & 14.81 & 26.01 \\
\hline LDPC & $86.49^{* *}$ & 4.47 & 27.85 & 7.52 \\
\hline VDPC & $27.50^{* *}$ & 1.18 & 15.88 & 6.82 \\
\hline $\mathrm{AM}$ & $0.74 * *$ & 0.03 & 0.95 & 17.64 \\
\hline $\mathrm{AL}$ & $49.27 * *$ & 2.73 & 23.39 & 7.17 \\
\hline LAT & $23.63^{* *}$ & 1.28 & 13.49 & 8.50 \\
\hline SAT & $5.78 * *$ & 0.25 & 4.79 & 10.43 \\
\hline Ratio AL/LAT & $0.16^{* *}$ & 0.02 & 1.75 & 6.47 \\
\hline \multicolumn{5}{|c|}{ Chemical-nutritional characteristics of almonds } \\
\hline $\mathrm{Ca}$ & $3180.19^{\mathrm{NS}}$ & 2622.80 & 152.39 & 33.61 \\
\hline $\mathrm{P}$ & $8692.44 * *$ & 370.15 & 361.17 & 5.33 \\
\hline K & $80391.37 * *$ & 8092.74 & 939.42 & 9.58 \\
\hline $\mathrm{Mg}$ & $4304.19 * *$ & 470.07 & 171.86 & 12.62 \\
\hline $\mathrm{Cu}$ & $0.57 * *$ & 0.02 & 1.24 & 11.00 \\
\hline $\mathrm{Mn}$ & $225.93 * *$ & 2.28 & 9.47 & 15.96 \\
\hline $\mathrm{Zn}$ & $1.32 * *$ & 0.33 & 3.82 & 15.08 \\
\hline $\mathrm{Fe}$ & $3.62 * *$ & 0.40 & 4.92 & 12.80 \\
\hline Crude protein & $5.52 * *$ & 0.33 & 15.41 & 3.73 \\
\hline Fat & $11.60 * *$ & 3.38 & 45.63 & 4.03 \\
\hline Crude fiber & $1.03 * *$ & 0.19 & 4.68 & 9.37 \\
\hline Ash & $0.17 * *$ & 0.03 & 2.68 & 6.42 \\
\hline Total carbohydrate & $12.74 * *$ & 3.87 & 34.28 & 5.74 \\
\hline Crude energy & $349.15 * *$ & 111.64 & 552.68 & 1.91 \\
\hline
\end{tabular}

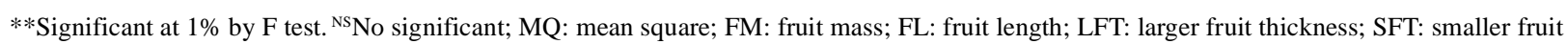
thickness; PM: pericarp mass; LDPC: longitudinal diameter of the pericarp cavity; VDPC: vertical diameter of the pericarp cavity; AM: almond mass; AL: almond length; LAT: larger almond thickness; SAT: smaller almond thickness 
Table 3 - Fruit physical characteristics of 23 castanheira-do-gurguéia genotypes collected in the southwestern savannah of Piauí State

\begin{tabular}{|c|c|c|c|c|c|c|c|c|c|}
\hline Genotypes $^{1}$ & FM $(g)$ & $\mathrm{FL}(\mathrm{mm})$ & LFT (mm) & FL/LFT ratio & $\mathrm{SFT}(\mathrm{mm})$ & FL/SFT ratio & $\mathrm{PM}(\mathrm{g})$ & LDPC (mm) & VDPC (mm) \\
\hline G-1 & $18.40 \mathrm{c}$ & $37.96 \mathrm{~d}$ & $35.97 \mathrm{c}$ & $1.05 \mathrm{~h}$ & $23.87 \mathrm{c}$ & $1.60 \mathrm{f}$ & $17.26 \mathrm{c}$ & $26.73 \mathrm{c}$ & $15.29 \mathrm{c}$ \\
\hline G-2 & $20.28 \mathrm{~b}$ & $41.44 \mathrm{~b}$ & $37.97 \mathrm{~b}$ & $1.09 \mathrm{~g}$ & $24.12 \mathrm{c}$ & $1.72 \mathrm{~d}$ & $18.75 \mathrm{~b}$ & $28.71 \mathrm{~b}$ & $17.34 \mathrm{~b}$ \\
\hline G-3 & $20.18 b$ & $37.90 \mathrm{~d}$ & $37.03 \mathrm{~b}$ & $1.02 \mathrm{i}$ & $25.70 \mathrm{a}$ & $1.48 \mathrm{~h}$ & $18.95 \mathrm{~b}$ & $30.01 \mathrm{~b}$ & $17.96 \mathrm{~b}$ \\
\hline G-4 & $15.05 \mathrm{~d}$ & $36.15 \mathrm{e}$ & $32.86 \mathrm{e}$ & $1.10 \mathrm{f}$ & $22.65 \mathrm{~d}$ & $1.60 \mathrm{f}$ & $13.87 \mathrm{~d}$ & $26.83 \mathrm{c}$ & $15.46 \mathrm{c}$ \\
\hline G-5 & $20.23 \mathrm{~b}$ & $39.75 \mathrm{c}$ & $35.85 \mathrm{c}$ & $1.11 \mathrm{f}$ & $24.50 \mathrm{~b}$ & $1.62 \mathrm{f}$ & $18.87 \mathrm{~b}$ & $28.89 \mathrm{~b}$ & 18.37 a \\
\hline G-6 & $11.14 \mathrm{e}$ & $32.84 \mathrm{~g}$ & $30.31 \mathrm{f}$ & $1.08 \mathrm{~g}$ & $20.98 \mathrm{e}$ & $1.59 \mathrm{f}$ & $10.35 \mathrm{e}$ & $23.95 \mathrm{~d}$ & $13.62 \mathrm{e}$ \\
\hline G-7 & $16.98 \mathrm{~d}$ & $40.35 \mathrm{c}$ & $35.23 \mathrm{c}$ & $1.14 \mathrm{e}$ & $21.18 \mathrm{e}$ & $1.92 \mathrm{~b}$ & $16.02 \mathrm{~d}$ & $30.27 \mathrm{~b}$ & $17.29 \mathrm{~b}$ \\
\hline G-8 & $11.26 \mathrm{e}$ & $37.12 \mathrm{e}$ & $30.59 \mathrm{f}$ & $1.21 \mathrm{~b}$ & $20.25 \mathrm{f}$ & $1.83 \mathrm{c}$ & $10.59 \mathrm{e}$ & $28.55 \mathrm{~b}$ & $13.83 \mathrm{e}$ \\
\hline G-9 & $15.37 \mathrm{~d}$ & $36.43 \mathrm{e}$ & $32.03 \mathrm{e}$ & $1.14 \mathrm{e}$ & $23.06 \mathrm{~d}$ & $1.58 \mathrm{f}$ & $14.64 \mathrm{~d}$ & $23.34 \mathrm{~d}$ & $13.44 \mathrm{e}$ \\
\hline G-10 & $8.43 \mathrm{f}$ & $31.92 \mathrm{~g}$ & $28.77 \mathrm{~g}$ & $1.11 \mathrm{f}$ & $17.33 \mathrm{~h}$ & $1.86 \mathrm{c}$ & $7.62 \mathrm{f}$ & $25.10 \mathrm{c}$ & $15.97 \mathrm{c}$ \\
\hline G-11 & $12.24 \mathrm{e}$ & $38.65 \mathrm{~d}$ & $32.07 \mathrm{e}$ & $1.21 \mathrm{~b}$ & $20.32 \mathrm{f}$ & $1.91 \mathrm{~b}$ & $11.20 \mathrm{e}$ & $31.98 \mathrm{a}$ & $17.62 \mathrm{~b}$ \\
\hline G-12 & $10.08 \mathrm{e}$ & $35.43 \mathrm{f}$ & $29.73 \mathrm{f}$ & $1.19 \mathrm{c}$ & $19.81 \mathrm{f}$ & $1.79 \mathrm{c}$ & $9.37 \mathrm{e}$ & $26.42 \mathrm{c}$ & $14.59 \mathrm{~d}$ \\
\hline G-13 & $8.86 \mathrm{f}$ & $33.29 \mathrm{~g}$ & $27.94 \mathrm{~g}$ & $1.19 \mathrm{c}$ & $17.63 \mathrm{~h}$ & $1.89 \mathrm{~b}$ & $8.38 \mathrm{f}$ & $25.43 \mathrm{c}$ & $15.00 \mathrm{c}$ \\
\hline G-14 & $15.86 \mathrm{~d}$ & $35.60 \mathrm{f}$ & $32.12 \mathrm{e}$ & $1.11 \mathrm{f}$ & $23.07 \mathrm{~d}$ & $1.54 \mathrm{~g}$ & $15.02 \mathrm{~d}$ & $27.25 \mathrm{c}$ & $15.02 \mathrm{c}$ \\
\hline G-15 & $15.48 \mathrm{~d}$ & $39.90 \mathrm{c}$ & $34.09 \mathrm{~d}$ & $1.17 \mathrm{~d}$ & $22.90 \mathrm{~d}$ & $1.74 \mathrm{~d}$ & $14.80 \mathrm{~d}$ & $30.79 \mathrm{~b}$ & $16.98 \mathrm{~b}$ \\
\hline G-16 & $20.16 b$ & $44.30 \mathrm{a}$ & $39.58 \mathrm{a}$ & $1.12 \mathrm{f}$ & $25.12 b$ & $1.76 \mathrm{~d}$ & $18.99 \mathrm{~b}$ & $33.66 \mathrm{a}$ & $17.76 \mathrm{~b}$ \\
\hline G-17 & $22.49 \mathrm{a}$ & $41.96 \mathrm{~b}$ & $37.41 \mathrm{~b}$ & $1.12 \mathrm{f}$ & $25.64 \mathrm{a}$ & $1.64 \mathrm{f}$ & $21.56 \mathrm{a}$ & $32.46 \mathrm{a}$ & $19.07 \mathrm{a}$ \\
\hline G-18 & $8.43 \mathrm{f}$ & $33.54 \mathrm{~g}$ & $29.89 \mathrm{f}$ & $1.12 \mathrm{f}$ & $19.05 \mathrm{~g}$ & $1.76 \mathrm{~d}$ & $7.41 \mathrm{f}$ & $25.66 \mathrm{c}$ & $16.25 \mathrm{c}$ \\
\hline G-19 & $12.38 \mathrm{e}$ & $40.94 \mathrm{~b}$ & $32.10 \mathrm{e}$ & $1.27 \mathrm{a}$ & $19.97 \mathrm{f}$ & $2.05 \mathrm{a}$ & $11.55 \mathrm{e}$ & $29.38 \mathrm{~b}$ & $15.09 \mathrm{c}$ \\
\hline G-20 & $18.43 \mathrm{c}$ & $42.52 \mathrm{~b}$ & $36.23 \mathrm{c}$ & $1.17 \mathrm{~d}$ & $23.12 \mathrm{~d}$ & $1.84 \mathrm{c}$ & $17.65 \mathrm{c}$ & $29.76 \mathrm{~b}$ & $15.88 \mathrm{c}$ \\
\hline G-21 & $11.55 \mathrm{e}$ & $34.83 \mathrm{f}$ & $31.30 \mathrm{e}$ & $1.11 \mathrm{f}$ & $20.42 \mathrm{f}$ & $1.71 \mathrm{e}$ & $10.85 \mathrm{e}$ & $25.99 \mathrm{c}$ & $15.48 \mathrm{c}$ \\
\hline G-22 & $6.36 \mathrm{~g}$ & $30.30 \mathrm{~h}$ & $28.03 \mathrm{~g}$ & $1.08 \mathrm{~g}$ & $18.76 \mathrm{~g}$ & $1.61 \mathrm{f}$ & $5.76 \mathrm{~g}$ & $22.71 \mathrm{~d}$ & $13.35 \mathrm{e}$ \\
\hline G-23 & $12.36 \mathrm{e}$ & $37.14 \mathrm{e}$ & $32.24 \mathrm{e}$ & $1.15 \mathrm{e}$ & $20.61 \mathrm{e}$ & $1.80 \mathrm{c}$ & $11.49 \mathrm{e}$ & $26.30 \mathrm{c}$ & $14.54 \mathrm{~d}$ \\
\hline Mean & 14.55 & 37.54 & 33.13 & 1.13 & 21.85 & 1.73 & 13.63 & 27.85 & 15.88 \\
\hline $\mathrm{CV}(\%)$ & 25.88 & 8.26 & 8.09 & 3.97 & 8.61 & 7.48 & 26.01 & 7.52 & 6.82 \\
\hline
\end{tabular}

${ }^{1}$ Means followed by the same letter in columns do not differ from each other by the Scott-Knott's test at 5\%. FM: fruit mass; FL: fruit length; LFT: larger fruit thickness; SFT: smaller fruit thickness; PM: pericarp mass; LDPC: longitudinal diameter of the pericarp cavity; VDPC: vertical diameter of the pericarp cavity

Table 4 - Physical characteristics of almonds of 23 castanheira-do-gurguéia genotypes collected in the southwestern savannah of Piauí State

\begin{tabular}{|c|c|c|c|c|c|}
\hline Genotypes $^{1}$ & $\mathrm{AM}(\mathrm{g})$ & $\mathrm{AL}(\mathrm{mm})$ & LAT (mm) & SAT (mm) & AL/LAT Ratio \\
\hline G-1 & $1.13 \mathrm{~d}$ & $23.37 \mathrm{c}$ & $13.55 \mathrm{~d}$ & $5.58 \mathrm{~b}$ & $2.45 \mathrm{c}$ \\
\hline G-2 & $1.45 \mathrm{~b}$ & $24.79 \mathrm{~b}$ & $15.16 \mathrm{c}$ & $6.34 \mathrm{a}$ & $2.31 \mathrm{~d}$ \\
\hline G-3 & $1.66 \mathrm{a}$ & $27.02 \mathrm{a}$ & $17.10 \mathrm{a}$ & $5.66 \mathrm{~b}$ & $2.37 \mathrm{~d}$ \\
\hline G-4 & $1.14 \mathrm{~d}$ & $24.19 \mathrm{~b}$ & $14.66 \mathrm{c}$ & $5.87 \mathrm{~b}$ & $2.36 \mathrm{~d}$ \\
\hline G-5 & $1.33 \mathrm{c}$ & $24.97 \mathrm{~b}$ & $15.76 \mathrm{~b}$ & $5.52 \mathrm{~b}$ & $2.35 \mathrm{~d}$ \\
\hline G-6 & $0.77 \mathrm{f}$ & $20.73 \mathrm{~d}$ & $12.15 \mathrm{e}$ & $5.14 \mathrm{c}$ & $2.40 \mathrm{~d}$ \\
\hline G-7 & $0.93 \mathrm{e}$ & $25.86 \mathrm{a}$ & $14.41 \mathrm{c}$ & $3.80 \mathrm{e}$ & $2.85 \mathrm{a}$ \\
\hline G-8 & $0.76 \mathrm{f}$ & $23.09 \mathrm{c}$ & $12.49 \mathrm{e}$ & $4.68 \mathrm{~d}$ & $2.69 \mathrm{~b}$ \\
\hline G-9 & $0.75 \mathrm{f}$ & $21.21 \mathrm{~d}$ & $12.32 \mathrm{e}$ & $4.97 \mathrm{c}$ & $2.46 \mathrm{c}$ \\
\hline G-10 & $0.81 \mathrm{f}$ & $22.28 \mathrm{c}$ & $14.56 \mathrm{c}$ & $4.18 \mathrm{~d}$ & $2.38 \mathrm{~d}$ \\
\hline G-11 & $1.05 \mathrm{~d}$ & $24.40 \mathrm{~b}$ & $12.97 \mathrm{~d}$ & $5.57 \mathrm{~b}$ & $2.63 \mathrm{~b}$ \\
\hline G-12 & $0.80 \mathrm{f}$ & $22.39 \mathrm{c}$ & $11.59 \mathrm{f}$ & $4.86 \mathrm{c}$ & $2.75 \mathrm{~b}$ \\
\hline G-13 & $0.57 \mathrm{f}$ & $20.72 \mathrm{~d}$ & $10.54 \mathrm{f}$ & $4.22 \mathrm{~d}$ & $2.81 \mathrm{a}$ \\
\hline
\end{tabular}


Continuação da Tabela 4

\begin{tabular}{lccccc}
\hline G-14 & $0.94 \mathrm{e}$ & $22.89 \mathrm{c}$ & $12.92 \mathrm{~d}$ & $4.97 \mathrm{c}$ & $2.56 \mathrm{c}$ \\
G-15 & $0.71 \mathrm{f}$ & $22.03 \mathrm{c}$ & $12.11 \mathrm{e}$ & $4.00 \mathrm{~d}$ & $2.74 \mathrm{~b}$ \\
G-16 & $1.24 \mathrm{c}$ & $26.73 \mathrm{a}$ & $14.44 \mathrm{c}$ & $4.86 \mathrm{c}$ & $2.78 \mathrm{a}$ \\
G-17 & $1.09 \mathrm{~d}$ & $27.21 \mathrm{a}$ & $15.15 \mathrm{c}$ & $4.06 \mathrm{~d}$ & $2.84 \mathrm{a}$ \\
G-18 & $0.96 \mathrm{e}$ & $21.32 \mathrm{~d}$ & $13.77 \mathrm{~d}$ & $5.30 \mathrm{c}$ & $2.25 \mathrm{~d}$ \\
G-19 & $0.86 \mathrm{e}$ & $24.09 \mathrm{~b}$ & $12.94 \mathrm{~d}$ & $4.16 \mathrm{~d}$ & $2.83 \mathrm{a}$ \\
G-20 & $0.77 \mathrm{f}$ & $25.39 \mathrm{~b}$ & $13.71 \mathrm{~d}$ & $3.61 \mathrm{e}$ & $2.93 \mathrm{a}$ \\
G-21 & $0.71 \mathrm{f}$ & $21.83 \mathrm{c}$ & $13.38 \mathrm{~d}$ & $3.67 \mathrm{e}$ & $2.56 \mathrm{c}$ \\
G-22 & $0.68 \mathrm{f}$ & $18.78 \mathrm{e}$ & $11.44 \mathrm{f}$ & $4.91 \mathrm{c}$ & $2.30 \mathrm{~d}$ \\
G-23 & $0.77 \mathrm{f}$ & $22.31 \mathrm{c}$ & $13.05 \mathrm{~d}$ & $4.36 \mathrm{~d}$ & $2.58 \mathrm{c}$ \\
\hline Mean & 0.95 & 23.39 & 13.49 & 4.79 & 2.57 \\
CV(\%) & 17.64 & 7.17 & 8.50 & 10.43 & 6.47 \\
\hline
\end{tabular}

${ }^{1}$ Means followed by the same letter in columns do not differ from each other by the Scott-Knott's test at 5\%. AM: almond mass; AL: almond length; LAT: larger almond thickness; SAT: smaller almond thickness

genotypes G-22 and G-17 had the lowest and the greatest means, respectively. The genotypes G-16 (33.66 mm), G-17 $(32.46 \mathrm{~mm})$ and G-11 $(31.98 \mathrm{~mm})$ presented the largest means for the longitudinal diameter of the pericarp cavity (LDPC), while the genotypes G-17 (19.07 mm) and G-5 $(18.37 \mathrm{~mm})$ presented the largest means for the vertical diameter of the pericarp cavity (VDPC). For the remaining characteristics, the differences observed, although significant, were of small range.

The genotype G-3 exhibited the highest value for almond mass (AM), with $1.66 \mathrm{~g}$, while the genotype G-13, with $0.57 \mathrm{~g}$ of $\mathrm{AM}$, exhibited the lowest mean for this trait. The genotypes G-2 (1.45 g) and G-5 (1.33 g) are also interesting, especially from the standpoint of future use in breeding programs of the species. Carvalho et al. (2008), working with almonds from a mixture of individuals, obtained $0.73 \mathrm{~g}$ of AM, a little smaller than the overall mean of $0.95 \mathrm{~g}$ obtained in this research. In general, there was the tendency that fruits with larger values of FM also had larger AM's values (TAB. 5). The genotypes G-17, G-3, G-16 and G-7 showed the largest means of almond length (AL), while the genotype G-3 showed the largest mean for the larger almond thickness (LAT).

Estimates of phenotypic correlation coefficients among nine fruit physical characteristics are shown in Table 5. Most of these correlation coefficients were positive and of high magnitude $\left(r_{p}>0.70\right)$, indicating that there should be no major problems in the selection process to improve agronomically important traits, such as FM. The highest phenotypic correlation was found between FM and smaller fruit thickness (SFT) $\left(r_{p}=0.97\right)$. FM showed high correlation coefficients with most of the physical characteristics studied, indicating that it can be of great importance in the selection process. Corrêa et al. (2008), in a study with baru walnut, also obtained high phenotypic correlations involving FM $\left[r_{p}=0.83\right.$ between FM and fruit length (FL); $r_{p}=0.92$ between $F M$ and larger fruit thickness (LFT); and $r_{p}=0.81$ between FM and SFT], which confirms the importance of FM, especially when one has in mind indirect genetic gain by selection. In this research, high phenotypic correlations were also obtained between FL and larger fruit thickness (LFT) $\left(r_{p}=0.91\right) ; \mathrm{FL}$ and AL $\left(r_{p}=0.90\right) ; \mathrm{FL}$ and longitudinal diameter of the pericarp cavity (LDPC) $\left(\mathrm{r}_{\mathrm{p}}=0.91\right)$; LFT and SFT $\left(r_{p}=0.93\right)$; LFT and AL $\left(r_{p}=0.89\right)$; AM and larger almond thickness (LAT) $\left(r_{p}=0.89\right)$; and FM and AM $\left(r_{p}=0.82\right)$. In the specific case of the FM and AM, the high phenotypic correlation coefficient between them is an indication that it is possible to increase the AM by indirect selection for larger or heavier fruit. Relatively low negative correlations were found for FL and smaller almond thickness (SAT) $\left(r_{p}=-0.17\right)$ and for SAT and LDPC $\left(r_{p}=-0.23\right)$, indicating that larger fruits tend to show less thicker almonds, and less thicker almonds tend to result in larger longitudinal pericarp cavities.

There were significant differences among genotypes for all chemical-nutritional characteristics analyzed, except for calcium (TAB. 6 and 7). The genotypes G-7 and G-23 prevailed in the crude protein concentration, with means of 18.03 and $17.24 \%$, respectively, and significantly differed from the other genotypes. On the other hand, the genotype G-5 showed the smallest mean for this characteristic (TAB. 6). The mean concentration of crude protein $(15.41 \%)$ found in this work is equivalent to the 
Table 5 - Estimates of the phenotypic correlation coefficients among physical characteristics of fruit and almond of 23 castanheira-do-gurguéia genotypes collected in the southwestern savannah of Piauí State

\begin{tabular}{|c|c|c|c|c|c|c|c|c|c|}
\hline Characteristics & FL & LFT & SFT & $\mathrm{AM}$ & $\mathrm{AL}$ & LAT & SAT & LDPC & VDPC \\
\hline FM & $0.85^{* *}$ & $0.96 * *$ & $0.97 * *$ & $0.82 * *$ & $0.87 * *$ & $0.75 * *$ & $0.33^{\mathrm{NS}}$ & $0.77 * *$ & $0.73 * *$ \\
\hline FL & & $0.91 * *$ & $0.76 * *$ & $0.70 * *$ & $0.90 * *$ & $0.57 *$ & $-0.17^{\mathrm{NS}}$ & $0.91 * *$ & $0.74 * *$ \\
\hline LFT & & & $0.93 * *$ & $0.86 * *$ & $0.89 * *$ & $0.77 * *$ & $0.39^{\mathrm{NS}}$ & $0.80^{* *}$ & $0.76^{* *}$ \\
\hline SFT & & & & $0.79^{* *}$ & $0.76^{* *}$ & $0.68 * *$ & $0.45^{\mathrm{NS}}$ & $0.56^{*}$ & $0.58^{*}$ \\
\hline AM & & & & & $0.77 * *$ & $0.89 * *$ & $0.73 * *$ & $0.56^{*}$ & $0.80^{* *}$ \\
\hline $\mathrm{AL}$ & & & & & & $0.84 * *$ & $0.22^{\mathrm{NS}}$ & $0.88^{* *}$ & $0.84 * *$ \\
\hline LAT & & & & & & & $0.46^{\mathrm{NS}}$ & $0.55 *$ & $0.82 * *$ \\
\hline SAT & & & & & & & & $-0.23^{\mathrm{NS}}$ & $0.27^{\mathrm{NS}}$ \\
\hline LDPC & & & & & & & & & $0.84 * *$ \\
\hline
\end{tabular}

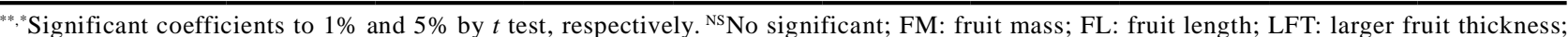
SFT: smaller fruit thickness; LDPC: longitudinal diameter of the pericarp cavity; VDPC: vertical diameter of the pericarp cavity; AM: almond mass; AL: almond length; LAT: larger almond thickness; SAT: smaller almond thickness

Table 6 - Chemical-nutritional characteristics of almonds of 23 castanheira-do-gurguéia genotypes collected in the southwestern savannah of Piauí State

\begin{tabular}{|c|c|c|c|c|c|c|}
\hline Genotypes $^{1}$ & Crude protein $(\%)$ & Fat $(\%)$ & Crude fiber $(\%)$ & $\operatorname{Ash}(\%)$ & Total carbohydrate (\%) & Crude energy (kcal $\left.100 \mathrm{~g}^{-1}\right)$ \\
\hline G-1 & $16.14 \mathrm{~b}$ & $47.31 \mathrm{a}$ & $4.21 \mathrm{~b}$ & $2.53 \mathrm{c}$ & $32.35 \mathrm{~b}$ & $544.89 \mathrm{~b}$ \\
\hline G-2 & $14.95 \mathrm{c}$ & $47.11 \mathrm{a}$ & $4.54 \mathrm{~b}$ & $2.67 \mathrm{c}$ & $33.40 \mathrm{~b}$ & $548.87 \mathrm{~b}$ \\
\hline G-3 & $15.51 \mathrm{c}$ & $48.06 \mathrm{a}$ & $3.44 \mathrm{~b}$ & $2.63 \mathrm{c}$ & $33.00 \mathrm{~b}$ & $551.23 \mathrm{a}$ \\
\hline G-4 & $16.63 \mathrm{~b}$ & $44.17 \mathrm{~b}$ & $3.97 \mathrm{~b}$ & $2.52 \mathrm{c}$ & $35.23 \mathrm{a}$ & $560.23 \mathrm{a}$ \\
\hline G-5 & $12.02 \mathrm{e}$ & $44.54 \mathrm{~b}$ & $5.01 \mathrm{a}$ & $2.60 \mathrm{c}$ & $38.42 \mathrm{a}$ & $572.07 \mathrm{a}$ \\
\hline G-6 & $13.97 \mathrm{~d}$ & $45.83 \mathrm{~b}$ & $5.19 \mathrm{a}$ & $2.37 \mathrm{c}$ & $35.01 \mathrm{a}$ & $554.28 \mathrm{a}$ \\
\hline G-7 & $18.03 \mathrm{a}$ & $43.10 \mathrm{~b}$ & $4.46 \mathrm{~b}$ & $2.52 \mathrm{c}$ & $34.41 \mathrm{a}$ & $554.17 \mathrm{a}$ \\
\hline G-8 & $15.54 \mathrm{c}$ & $47.07 \mathrm{a}$ & $5.08 \mathrm{a}$ & $2.75 \mathrm{c}$ & $32.31 \mathrm{~b}$ & $541.24 \mathrm{~b}$ \\
\hline G-9 & $15.84 \mathrm{c}$ & $47.69 \mathrm{a}$ & $4.85 \mathrm{a}$ & $2.63 \mathrm{c}$ & $31.63 \mathrm{~b}$ & $538.74 \mathrm{~b}$ \\
\hline G-10 & $16.42 \mathrm{~b}$ & $42.22 \mathrm{~b}$ & $4.87 \mathrm{a}$ & $3.08 \mathrm{a}$ & 36.49 a & $562.97 \mathrm{a}$ \\
\hline G-11 & $14.71 \mathrm{c}$ & $44.69 \mathrm{~b}$ & $5.00 \mathrm{a}$ & $2.33 \mathrm{c}$ & $35.59 \mathrm{a}$ & $557.93 \mathrm{a}$ \\
\hline G-12 & $15.37 \mathrm{c}$ & $50.74 \mathrm{a}$ & $5.21 \mathrm{a}$ & $2.45 \mathrm{c}$ & $28.68 \mathrm{~b}$ & $522.56 \mathrm{~b}$ \\
\hline G-13 & $15.11 \mathrm{c}$ & $45.12 \mathrm{~b}$ & $4.76 \mathrm{a}$ & $2.85 \mathrm{~b}$ & $35.01 \mathrm{a}$ & $556.00 \mathrm{a}$ \\
\hline G-14 & $15.38 \mathrm{c}$ & $46.03 \mathrm{~b}$ & $4.26 \mathrm{~b}$ & $2.70 \mathrm{c}$ & $34.33 \mathrm{a}$ & $554.63 \mathrm{a}$ \\
\hline G-15 & $13.29 \mathrm{~d}$ & $45.49 \mathrm{~b}$ & $5.30 \mathrm{a}$ & $2.91 \mathrm{~b}$ & $35.93 \mathrm{a}$ & $558.43 \mathrm{a}$ \\
\hline G-16 & $15.86 \mathrm{c}$ & $44.35 \mathrm{~b}$ & $4.20 \mathrm{~b}$ & $2.88 \mathrm{~b}$ & $35.58 \mathrm{a}$ & $561.08 \mathrm{a}$ \\
\hline G-17 & $12.98 \mathrm{~d}$ & $46.04 \mathrm{~b}$ & $5.24 \mathrm{a}$ & $2.66 \mathrm{c}$ & $35.75 \mathrm{a}$ & $557.77 \mathrm{a}$ \\
\hline G-18 & $15.43 \mathrm{c}$ & $47.82 \mathrm{a}$ & $4.70 \mathrm{a}$ & $2.38 \mathrm{c}$ & $32.06 \mathrm{~b}$ & $541.46 \mathrm{~b}$ \\
\hline G-19 & $16.47 \mathrm{~b}$ & $42.97 \mathrm{~b}$ & $3.70 \mathrm{~b}$ & $2.53 \mathrm{c}$ & $36.86 \mathrm{a}$ & $569.50 \mathrm{a}$ \\
\hline G-20 & $15.90 \mathrm{c}$ & $44.88 \mathrm{~b}$ & $5.46 \mathrm{a}$ & $2.99 \mathrm{~b}$ & $33.75 \mathrm{~b}$ & $546.89 \mathrm{~b}$ \\
\hline G-21 & $15.34 \mathrm{c}$ & $45.82 \mathrm{~b}$ & $4.43 \mathrm{~b}$ & $2.65 \mathrm{c}$ & $34.41 \mathrm{a}$ & $554.33 \mathrm{a}$ \\
\hline G-22 & $16.21 \mathrm{~b}$ & $44.96 \mathrm{~b}$ & $4.05 \mathrm{~b}$ & $2.68 \mathrm{c}$ & $34.78 \mathrm{a}$ & $557.71 \mathrm{a}$ \\
\hline G-23 & $17.24 \mathrm{a}$ & $43.53 \mathrm{~b}$ & $5.72 \mathrm{a}$ & $3.29 \mathrm{a}$ & $33.51 \mathrm{~b}$ & $544.65 \mathrm{~b}$ \\
\hline Mean & 15.41 & 45.63 & 4.68 & 2.68 & 34.28 & 552.68 \\
\hline $\mathrm{CV}(\%)$ & 3.73 & 4.03 & 9.37 & 6.42 & 5.74 & 1.91 \\
\hline
\end{tabular}

${ }^{1}$ Means followed by the same letter in columns do not statistically differ from each other by the Scott-Knott's grouping test at 5\% 
Table 7 - Mineral concentration in almonds of 23 castanheira-do-gurguéia genotypes collected in the southwestern savannah of Piauí State

\begin{tabular}{|c|c|c|c|c|c|c|c|c|}
\hline \multirow{2}{*}{ Genotypes $^{1}$} & $\mathrm{Ca}$ & $\mathrm{P}$ & $\mathrm{K}$ & $\mathrm{Mg}$ & $\mathrm{Cu}$ & $\mathrm{Mn}$ & $\mathrm{Zn}$ & $\mathrm{Fe}$ \\
\hline & \multicolumn{8}{|c|}{--------------------------------------------------------'mg $100 \mathrm{~g}^{-1}$} \\
\hline G-1 & $133.10 \mathrm{a}$ & $420.63 \mathrm{~b}$ & $762.59 \mathrm{c}$ & $146.08 \mathrm{c}$ & $1.49 \mathrm{c}$ & $2.51 \mathrm{~d}$ & $4.49 \mathrm{a}$ & $4.33 \mathrm{~b}$ \\
\hline G-2 & $212.03 \mathrm{a}$ & $457.55 \mathrm{a}$ & $933.30 \mathrm{c}$ & $135.16 \mathrm{~d}$ & $1.06 \mathrm{~d}$ & $2.30 \mathrm{~d}$ & $4.06 \mathrm{a}$ & $4.44 \mathrm{~b}$ \\
\hline G-3 & $101.68 \mathrm{a}$ & $357.07 \mathrm{c}$ & $981.45 \mathrm{~b}$ & $180.29 \mathrm{~b}$ & $1.09 \mathrm{~d}$ & $6.01 \mathrm{~d}$ & $4.35 \mathrm{a}$ & $4.24 \mathrm{~b}$ \\
\hline G-4 & $164.46 \mathrm{a}$ & $364.78 \mathrm{c}$ & $819.59 \mathrm{c}$ & $166.24 \mathrm{c}$ & $1.59 \mathrm{~b}$ & $20.88 \mathrm{~b}$ & $4.53 \mathrm{a}$ & $4.61 \mathrm{~b}$ \\
\hline G-5 & $107.26 \mathrm{a}$ & $354.38 \mathrm{c}$ & $1017.64 \mathrm{~b}$ & $223.36 \mathrm{a}$ & $0.88 \mathrm{e}$ & $10.41 \mathrm{c}$ & $3.14 \mathrm{~b}$ & $4.47 \mathrm{~b}$ \\
\hline G-6 & $190.82 \mathrm{a}$ & $348.17 \mathrm{c}$ & $705.61 \mathrm{c}$ & $102.22 \mathrm{~d}$ & $0.29 \mathrm{f}$ & $3.55 \mathrm{~d}$ & $3.15 \mathrm{~b}$ & $7.60 \mathrm{a}$ \\
\hline G-7 & $155.43 \mathrm{a}$ & $375.35 \mathrm{c}$ & $793.60 \mathrm{c}$ & $246.23 \mathrm{a}$ & $2.20 \mathrm{a}$ & $10.11 \mathrm{c}$ & $5.06 \mathrm{a}$ & $5.08 \mathrm{~b}$ \\
\hline G-8 & $146.85 \mathrm{a}$ & $357.19 \mathrm{c}$ & $914.20 \mathrm{c}$ & $240.72 \mathrm{a}$ & $1.28 \mathrm{~d}$ & $7.95 \mathrm{c}$ & $4.13 \mathrm{a}$ & $4.72 \mathrm{~b}$ \\
\hline G-9 & $122.72 \mathrm{a}$ & $356.77 \mathrm{c}$ & $930.09 \mathrm{c}$ & $178.73 \mathrm{~b}$ & $1.31 \mathrm{~d}$ & $8.59 \mathrm{c}$ & $4.24 \mathrm{a}$ & $6.62 \mathrm{a}$ \\
\hline G-10 & $210.23 \mathrm{a}$ & $443.08 \mathrm{a}$ & $1037.65 \mathrm{~b}$ & $153.07 \mathrm{c}$ & $1.11 \mathrm{~d}$ & $7.24 \mathrm{c}$ & $4.21 \mathrm{a}$ & $4.96 \mathrm{~b}$ \\
\hline G-11 & $154.23 \mathrm{a}$ & $325.73 \mathrm{~d}$ & $739.78 \mathrm{c}$ & $124.57 \mathrm{~d}$ & $1.12 \mathrm{~d}$ & $4.53 \mathrm{~d}$ & $3.57 \mathrm{~b}$ & $6.86 \mathrm{a}$ \\
\hline G-12 & $134.46 \mathrm{a}$ & $281.79 \mathrm{e}$ & $1007.78 \mathrm{~b}$ & $129.59 \mathrm{~d}$ & $0.76 \mathrm{e}$ & $4.03 \mathrm{~d}$ & $3.30 \mathrm{~b}$ & $4.04 \mathrm{~b}$ \\
\hline G-13 & $127.76 \mathrm{a}$ & $325.55 \mathrm{~d}$ & $1200.78 \mathrm{a}$ & $195.51 \mathrm{~b}$ & $0.93 \mathrm{e}$ & $3.89 \mathrm{~d}$ & $3.64 \mathrm{~b}$ & $7.26 \mathrm{a}$ \\
\hline G-14 & $165.21 \mathrm{a}$ & $270.52 \mathrm{e}$ & $985.44 \mathrm{~b}$ & $151.36 \mathrm{c}$ & $2.12 \mathrm{a}$ & $5.34 \mathrm{~d}$ & $2.92 \mathrm{~b}$ & $3.99 \mathrm{~b}$ \\
\hline G-15 & $191.53 \mathrm{a}$ & $276.40 \mathrm{e}$ & $1261.35 \mathrm{a}$ & $121.82 \mathrm{~d}$ & $0.91 \mathrm{e}$ & $3.63 \mathrm{~d}$ & $3.45 \mathrm{~b}$ & $4.20 \mathrm{~b}$ \\
\hline G-16 & $130.61 \mathrm{a}$ & $399.15 \mathrm{~b}$ & $1150.50 \mathrm{a}$ & $156.73 \mathrm{c}$ & $0.98 \mathrm{e}$ & $2.79 \mathrm{~d}$ & $3.34 \mathrm{~b}$ & $4.07 \mathrm{~b}$ \\
\hline G-17 & $129.54 \mathrm{a}$ & $305.07 \mathrm{e}$ & $848.66 \mathrm{c}$ & $209.29 \mathrm{~b}$ & $1.06 \mathrm{~d}$ & $9.92 \mathrm{c}$ & $2.66 \mathrm{~b}$ & $3.70 \mathrm{~b}$ \\
\hline G-18 & $145.87 \mathrm{a}$ & $333.06 \mathrm{~d}$ & $832.25 \mathrm{c}$ & $173.08 \mathrm{c}$ & $1.38 \mathrm{c}$ & $8.36 \mathrm{c}$ & $4.03 \mathrm{a}$ & $4.43 \mathrm{~b}$ \\
\hline G-19 & $115.21 \mathrm{a}$ & $368.34 \mathrm{c}$ & $732.84 \mathrm{c}$ & $170.32 \mathrm{c}$ & $1.01 \mathrm{e}$ & $8.83 \mathrm{c}$ & $3.98 \mathrm{a}$ & $4.41 \mathrm{~b}$ \\
\hline G-20 & $187.90 \mathrm{a}$ & $404.91 \mathrm{~b}$ & $1044.32 \mathrm{~b}$ & $200.60 \mathrm{~b}$ & $1.65 \mathrm{~b}$ & $7.79 \mathrm{c}$ & $5.03 \mathrm{a}$ & $5.24 \mathrm{~b}$ \\
\hline G-21 & $119.10 \mathrm{a}$ & $353.90 \mathrm{c}$ & $820.34 \mathrm{c}$ & $199.90 \mathrm{~b}$ & $1.48 \mathrm{c}$ & $18.65 \mathrm{~b}$ & $3.38 \mathrm{~b}$ & $4.33 \mathrm{~b}$ \\
\hline G-22 & $177.86 \mathrm{a}$ & $356.53 \mathrm{c}$ & $846.84 \mathrm{c}$ & $189.94 \mathrm{~b}$ & $1.80 \mathrm{~b}$ & $41.17 \mathrm{a}$ & $4.15 \mathrm{a}$ & $5.23 \mathrm{~b}$ \\
\hline G-23 & $181.17 \mathrm{a}$ & $471.09 \mathrm{a}$ & $1240.06 \mathrm{a}$ & $157.87 \mathrm{c}$ & $1.07 \mathrm{~d}$ & $19.26 \mathrm{~b}$ & $2.95 \mathrm{~b}$ & $4.24 \mathrm{~b}$ \\
\hline Mean & 152.39 & 361.17 & 939.42 & 171.86 & 1.24 & 9.47 & 3.82 & 4.92 \\
\hline $\mathrm{CV}(\%)$ & 33.61 & 5.33 & 9.58 & 12.62 & 11.00 & 15.96 & 15.08 & 12.80 \\
\hline
\end{tabular}

${ }^{1}$ Means followed by the same letter in columns do not differ from each other by the Scott-Knott's grouping test at $5 \%$

one reported by Carvalho et al. (2008), also for the almond of the castanheira-do-gurguéia, and lower than those obtained by Takemoto et al. (2001) and Vera et al. (2009) for baru walnut, whose means were $23.9 \%$ and $26.2 \%$, respectively. However, in comparison to several other almonds one can consider castanha-do-gurguéia as a good source of proteins, presenting values higher than those reported by Crepaldi et al. (2001) for licuri nut (11.5\%); United States Department of Agriculture (2007) and Oro et al. (2008) for pecan nut (9.2-10.4\%); United States Department of Agriculture (2007) for nutmeg (5.8\%) and macadamia (7.9\%); and equivalent to those obtained by (TABELA..., 2006) for Brazil nut (14.5\%) and European walnut (18.6\%); Carvalho et al. (2008) for chichá nut $(17,4 \%)$ and sapucaia nut (18.5\%), and by Souza et al. (2008) also for sapucaia nut (19.6\%). Only cashew nut (24.5\%) (LIMA et al., 2004), peanut (25.8-27.2\%) (TABELA..., 2006; UNITED STATES DEPARTMENT OF AGRICULTURE, 2007), European walnut $(24.9 \%)$ (UNITED STATES DEPARTMENT OF AGRICULTURE, 2007) and pequi almond (25.3\%) (LIMA et al., 2007) are richer in protein than the almond of the castanheira-do-gurguéia.

The fat concentration varied from $42.22 \%(\mathrm{G}-10)$ to $50.74 \%$ (G-12), with a mean of $45.63 \%$. In addition to genotype G-12, also presented high fat concentrations the genotypes G-3, G-18, G-1, G-2, G-8 and G-9, with means between $47 \%$ and $48 \%$ (TAB. 6). The mean fat concentration of $45.63 \%$ found in this work is a little higher than that obtained by Carvalho et al. (2008) also for the almond of the castanheira-do-gurguéia (41.9\%), 
and much higher than those obtained by Takemoto et al. (2001) and Vera et al. (2009) for baru walnut, with means of $38.2 \%$ and $33.3 \%$, respectively; United States Department of Agriculture (2007) for nutmeg (36.3\%), and by Carvalho et al. (2008) for chichá nut (27.7\%). This fat concentration is equivalent to those reported for cashew nut $(47.7 \%)$ (TABELA..., 2006) and pistachio (44.4\%) (UNITED STATES DEPARTMENT OF AGRICULTURE, 2007). However, it is much lower than those obtained for European walnut (57.0\%), hazelnut (60.8\%) and Brazil nut (63.5\%-66.6\%) (TABELA..., 2006; UNITED STATES DEPARTMENT OF AGRICULTURE, 2007), pecan nut (72.0\%) and macadamia (75.5\%-75.8\%) (TABELA..., 2006; UNITED STATES DEPARTMENT OF AGRICULTURE, 2007). It is also much lower than the fat concentrations obtained by Carvalho et al. (2008) and Souza et al. (2008) for sapucaia nut (64.0\% and $66.0 \%$ respectively). However, regarding the human consumption, lower fat concentration almonds are desirable and, in this case, the castanha-do-gurguéia is placed on an intermediate level, and its consumption is, in theory, healthier than Brazil nut and macadamia, for example. Moreover, with a mean fat concentration around $45 \%$, the castanha-dogurguéia has also a potential to be used as an alternative source of raw material for the biodiesel production.

The crude fiber concentration of the almond ranged from $3.44 \%$ to $5.72 \%$, with a mean of $4.68 \%$. It can be observed that over $50 \%$ of the genotypes showed mean concentrations of this nutrient higher than $4.7 \%$ (TAB. 6). On mean, the crude fiber concentration found in this work is lower than that obtained by Carvalho et al. (2008) for the almond of the same species (6.1\%); Souza et al. (2008) for sapucaia nut (7.0\%), and by (TABELA.., 2006) for Brazil nut (7.9\%). Nevertheless, it is higher than the mean concentration of $2.2 \%$ obtained by Lima et al. (2007) for pequi almond.

As regards the ash concentration, it can be observed that there was a variation from $2.33 \%$ to $3.29 \%$, being G-10 (3.08\%) and G-23 (3.29\%) the genotypes with the highest means, while the genotype G-11 had the lowest mean (TAB. 6). In general, comparing the ash mean concentration of the almonds $(2.68 \%)$ found in this work, it can be seen that it is a little higher than those obtained by Carvalho et al. (2008) also for the castanha-do-gurguéia (2.5\%); Lima et al. (2004) for cashew nut $(2.5 \%)$; (TABELA..., 2006) for peanut $(2.2 \%)$ and European walnut (2.1\%), and by the United States Department of Agriculture (2007) for hazelnut (2.3\%) and nutmeg $(2.3 \%)$, and it is much higher than the ash mean concentration for reported for macadamia (1.1\%) and pecan nut (1.5\%) (UNITED STATES DEPARTMENT OF AGRICULTURE, 2007). However, it is lower than the ash mean concentrations reported by Carvalho et al. (2008) for chichá nut (3.2\%), and by Souza et al. (2008) and Carvalho et al. (2008) for sapucaia nut (3.1 and 3.4\% respectively). Even so, the results found in this study indicate that the castanha-do-gurguéia is an important ash source as compared to other almonds.

Concerning the total carbohydrate concentration, there was variation from $28.68 \%(\mathrm{G}-12)$ to $38.42 \%$ (G-5), with a mean of $34.28 \%$. Fourteen from the 23 genotypes presented mean concentration of this nutrient equal to or higher than $34.33 \%$ and differed from the other genotypes (TAB. 6). Carvalho et al. (2008), working with mixtures of castanha-dogurguéia almonds, sapucaia nut and chichá nut, obtained, for the castanha-do-gurguéia, a mean value of total carbohydrate (36.2\%) equivalent to the overall genotypes's mean found in this work. Nevertheless, this author obtained a much higher mean concentration for chichá nut $(45.1 \%)$ and a much lower value for sapucaia nut $(11.1 \%)$. In (TABELA..., 2006), it is mentioned a mean concentration of $15.1 \%$ of carbohydrate for Brazil nut, which shows that the castanha-do-gurguéia is a reasonable source of this nutrient.

Fifteen of the 23 genotypes of castanheira-do-gurguéia studied presented mean energy concentrations equal to or higher than $551.23 \mathrm{kcal} 100 \mathrm{~g}^{-1}$, with values ranging from

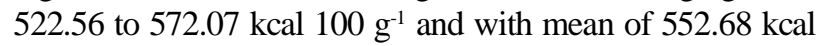
$100 \mathrm{~g}^{-1}$ (TAB. 6). On mean the results obtained in this study are lower than those achieved by Carvalho (2005) for almond of the same species (578.5 kcal $\left.100 \mathrm{~g}^{-1}\right)$ and for sapucaia nut

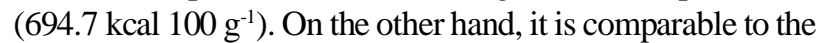
energy concentrations of other almond types, such as peanut (544 kcal $100 \mathrm{~g}^{-1}$ ) (TABELA..., 2006) and licuri almond (527.3 kcal $\left.100 \mathrm{~g}^{-1}\right)$ (CREPALDI et al., 2001), and higher than

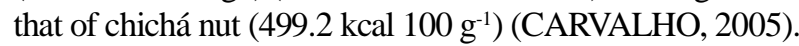

The $\mathrm{P}, \mathrm{K}$ and $\mathrm{Mg}$ concentrations in the almond ranged from 270.52 to $471.09 \mathrm{mg} 100 \mathrm{~g}^{-1}$; from 705.61 to

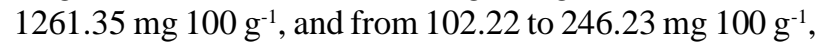
respectively. The genotypes G-23, G-2 and G-10 exhibited preponderance over the concentrations of $\mathrm{P}$, while the genotypes G-15, G-23, G-13 and G-16 outperformed the others in the $\mathrm{K}$ concentration. The genotypes G-5, G-7 and G-8 exhibited the highest means for $\mathrm{Mg}$ (TAB. 7). The mean concentrations for $\mathrm{P}\left(361.17 \mathrm{mg} 100 \mathrm{~g}^{-1}\right), \mathrm{K}$ (939.42 mg $100 \mathrm{~g}^{-1}$ ) and $\mathrm{Mg}$ (171.86 mg $100 \mathrm{~g}^{-1}$ ) obtained in this study are higher than those reported for the baru walnut (TAKEMOTO et al., 2001), macadamia (UNITED STATES DEPARTMENT OF AGRICULTURE, 2007) and pecan nut (UNITED STATES DEPARTMENT OF AGRICULTURE, 2007). However, they are lower than those reported by Souza et al. (2008) for sapucaia nut; (TABELA..., 2006) for Brazil nut and by Morgano et al. (2002) for hazelnut and pistachio. 
The results obtained in this work indicate that the castanha-do-gurguéia almond is very rich in $\mathrm{K}$, especially when compared to hazelnut (681.7-704.7 mg $\left.100 \mathrm{~g}^{-1}\right)$, European walnut (291.9 mg $\left.100 \mathrm{~g}^{-1}\right)$, pecan nut (433.4-

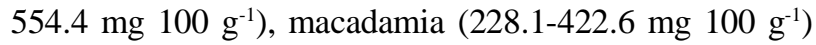
(MORGANO et al., 2002), sapucaia nut (674.59 $\mathrm{mg} \mathrm{100g}^{-1}$ )

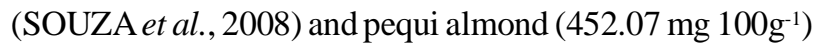
(OLIVEIRA et al., 2010). The genotype G-15 (1261.35 mg $\left.100 \mathrm{~g}^{-1}\right)$, specifically, seems greatly promising for using in future genetic breeding programs, outperforming the mean concentrations reported for the majority of the almonds, as already cited.

Concerning the micronutrients concentration, there was also a significant variation among genotypes (Cu: 0.29-2.20 mg $100 \mathrm{~g}^{-1}$; Mn: 2.30-41.17 mg $100 \mathrm{~g}^{-1}$; Zn: 2.66-5.06 mg $100 \mathrm{~g}^{-1}$, and Fe 3.70-7.60 mg $100 \mathrm{~g}^{-1}$ ). The genotypes G-7 and G-14 stood out for the $\mathrm{Cu}$; the genotype G-22 stood out for the concentration of $\mathrm{Mn}$, and the genotypes G-6, G-9, G-11 and G-13 had the highest means for the concentration of $\mathrm{Fe}$. As for $\mathrm{Zn}, 12$ of the 23 genotypes analyzed exhibited means higher than $3.98 \mathrm{mg}$ $100 \mathrm{~g}^{-1}$ (TAB. 7).

In general, the mean concentration of $\mathrm{Cu}(1.24$ mg $\left.100 \mathrm{~g}^{-1}\right)$, Mn (9.47 mg $\left.100 \mathrm{~g}^{-1}\right), \mathrm{Zn}\left(3.82 \mathrm{mg} 100 \mathrm{~g}^{-1}\right)$ and $\mathrm{Fe}\left(4.92 \mathrm{mg} 100 \mathrm{~g}^{-1}\right)$ are lower than those obtained by Carvalho (2005) for the almond of the same species (1.9; 20.2; 6.6; and $7.8 \mathrm{mg} 100 \mathrm{~g}^{-1}$, respectively). The mean concentration of $\mathrm{Zn}$ was also lower than the mean concentrations obtained for sapucaia nut $\left(7.1 \mathrm{mg} 100 \mathrm{~g}^{-1}\right)$ and chichá nut (12.7 mg $100 \mathrm{~g}^{-1}$ ) (CARVALHO, 2005), and for baru walnut (4.1 mg $100 \mathrm{~g}^{-1}$ ) (TAKEMOTO et al., 2001). Likewise, the mean $\mathrm{Cu}$ concentration was lower than those obtained by Takemoto et al. (2001) and by Vera et al. (2009) for baru walnut $\left(1.45 \mathrm{mg} 100 \mathrm{~g}^{-1}\right.$ and

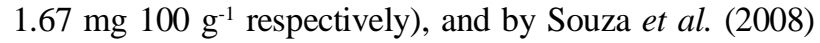
for sapucaia nut (3.04 mg $\left.100 \mathrm{~g}^{-1}\right)$. Whereas, the mean $\mathrm{Mn}$ concentration is also lower than the mean concentration obtained for sapucaia nut (18.1 mg $100 \mathrm{~g}^{-1}$ ) (CARVALHO, 2005). However, it is higher than the mean concentrations reported by Vera et al. (2009) for baru walnut $(5.72 \mathrm{mg}$ $\left.100 \mathrm{~g}^{-1}\right)$; Carvalho (2005) for chichá nut (1.8 mg $\left.100 \mathrm{~g}^{-1}\right)$, and by (TABELA..., 2006) for Brazil nut $(1.10 \mathrm{mg} 100$ $\left.\mathrm{g}^{-1}\right)$. At last, the mean Fe concentration is still lower than that reported by Vera et al. (2009) for baru walnut (19.81 mg $\left.100 \mathrm{~g}^{-1}\right)$. Nevertheless, it was higher than the mean concentration obtained by Takemoto et al. (2001), also for baru walnut (4.24 mg $100 \mathrm{~g}^{-1}$ ).

Making a correlation between the results of the physical characteristics, especially AM, with those of the chemical-nutritional characteristics, it is observed that the genotypes G-3, G-13, G-23, G-10 and G-7 are important sources of genes for using in forthcoming genetic breeding programs of this species. The G-3 obtained the largest AM, although it is not among the better performing genotypes in chemical-nutritional concentration and the others, by the more complete centesimal composition in mean terms.

\section{Conclusions}

1. In general, the genotypes of castanheira-do-gurguéia presented significant phenotypic variability formost of the physical and chemical-nutritional characteristics, indicating that this variability is important for using in future genetic breeding programs of the species;

2. The high phenotypic correlation estimate obtained between fruit mass and almond mass indicates that it is possible to increase the almond size by the selection for larger fruit mass;

3. Genotypes with larger fruit length means do not result, necessarily, in larger smaller almond thickness means, as well as genotypes with larger smaller almond thickness do not result in larger longitudinal diameter of the pericarp cavity means;

4. The genotype G-3 is the most promising in terms of almond mass, almond length and larger almond thickness, and the genotypes G-7, G-10, G-13 and G23 are the most promising in the chemical-nutritional composition and, therefore, are important sources of genes that may be exploited in future breeding programs of the species.

\section{Agradecimentos}

À CAPES, pela bolsa concedida.

À Embrapa Meio-Norte e a Universidade Federal do Piauí - UFPI, pela possibilidade de realizar as análises físicas e químico-nutricionais.

Ao Dr. Valdomiro Aurélio Barbosa de Souza (in memoriam), pela orientação valiosa e pela iniciação no campo da pesquisa.

Ao Dr. Vidal de Freitas Mansano, pesquisador do Instituto de Pesquisas Jardim Botânico do Rio de Janeiro, pela identificação do material botânico.

\section{References}

CARVAlHO, M. G. Caracterização nutricional de nozes de chichá, castanha-do-gurguéia e sapucaia, in natura e torradas. 2005. $41 \mathrm{f}$. Monografia (Graduação em Tecnologia de Alimentos) - Centro Federal de Educação Tecnológica do Piauí, Teresina. 
CARVALHO, M. G. Barras de cereais com amêndoas de chichá, sapucaia e castanha-do-gurguéia, complementadas com casca de abacaxi. 2008. 92 f. Dissertação (Mestrado em Tecnologia de Alimentos) - Universidade Federal do Ceará, Ceará.

CARVALHO, M. G. et al. Avaliação dos parâmetros físicos e nutricionais de amêndoas de chichá, sapucaia e castanhado-gurguéia. Revista Ciência Agronômica, v. 39, n. 04, p. 517-523, 2008.

CORRÊA, G. de C. et al. Determinações físicas em frutos e sementes de baru (Dipteryx alata Vog.), cajuzinho (Anacardium othonianum Rizz.) e pequi (Caryocar brasiliense Camb.), visando melhoramento genético. Bioscience Journal, v. 24, n. 04, p. 42-47, 2008.

CREPALDI, I. C. et al. Composição nutricional do fruto de licuri (Syagrus coronata Martius) Beccari). Revista Brasileira de Botânica, v. 24, n. 02, p.155-159, 2001.

DUCKE, A. As espécies brasileiras do gênero Coumarouna Aubl. ou Dipteryx Schreb. Academia Brasileira de Ciências, v. 20, n. 01, p. 39-56, 1948.

INSTITUTO ADOLFO LUTZ (IAL). Métodos físicoquímicos para análise de alimentos. 4. ed. São Paulo: IAL, 2005. 1015 p.

LIMA, A. C.; GARCIA, N. H. P.; LIMA, J. R. Obtenção e caracterização dos principais produtos do caju. Boletim do Centro de Pesquisa de Processamento de Alimentos, v. 22, n. 01, p. 133-144, 2004.

LIMA, A. de. et al. Composição química e compostos bioativos presentes na polpa e na amêndoa do pequi (Caryocar brasiliense Camb.). Revista Brasileira de Fruticultura, v. 29, n. 03, p. 695-698, 2007.

MORGANO, M. A. et al. Caracterização mineral de diferentes nozes. In: CONGRESSO BRASILEIRO DE CIÊNCIA E TECNOLOGIA DE ALIMENTOS, 18., 2002, Porto Alegre. Anais... Porto Alegre: SBCTA, 2002. p. 3752-3755.
OLIVEIRA, M.E.B. de et al. Características químicas e físicoquímicas de pequis da chapada do Araripe, Ceará. Revista Brasileira de Fruticultura, v. 32, n. 01, p. 114-125, 2010.

ORO, T. et al. Evaluación de la calidad durante el almacenamiento de nueces Pecán [Carya illinoinensis (Wangenh.) C. Koch] acondicionadas en diferentes envases. Grasas y Aceites, v. 59, n. 02, p. 132-138, 2008.

RATTER, J. A.; RIBEIRO, J. F. Biodiversity of the flora of the cerrado. In: SIMPÓSIO SOBRE O CERRADO, 8., Brasília. Anais... Brasília: EMBRAPA-CPAC, 1996. p. 3-5.

SILVA, J. M. C. da.; BATES, J. M. Biogeographic patterns and conservation in the South American Cerrado: a tropical savanna hotspot. BioScience, v. 52, n. 03, p. 225-233, 2002.

SOUZA, V. A. B. et al. Características físicas de frutos e amêndoas e características químico-nutricionais de amêndoas de acessos de sapucaia. Revista Brasileira de Fruticultura, v. 30, n. 04, p. 946-952, 2008.

TABELA Brasileira de Composição de Alimentos. 2. ed. Campinas: NEPA-UNICAMP, 2006. 113 p.

TAKEMOTO, E. et al. Composição química da semente e do óleo de baru (Dipteryx alata Vog.) nativo do município de Pirenópolis, estado de Goiás. Revista do Instituto Adolfo Lutz, v. 60, n. 02 , p. 113-117, 2001.

UNITED STATES DEPARTMENT OF AGRICULTURE (USDA). Agricultural Research Service. National Nutrient database for standard reference, Release 20, 2007. Disponível em: <http://www. ars.usda.gov/ba/bhnrc/ndl>. Acesso em: 20 jan. 2008.

VERA, R. et al. Características químicas de amêndoas de barueiros (Dipteryx alata Vog.) de ocorrência natural no cerrado do estado de Goiás, Brasil. Revista Brasileira de Fruticultura, v. 31, n. 01, p. 112-118, 2009.

VIEIRA JÚNIOR, G. M. et al. Terpenos e ácidos graxos de Dipteryx lacunifera Ducke. Química Nova, v. 30, n. 07, p. 1658-1662, 2007. 